解 説

\title{
大型ヘリカル装置の極低温構造材料と構造設計
}

\author{
西 村 新, 今川 信作, 田 村 仁 \\ 核融合科学研究所 土岐市下石町 322-6 \\ (1997 年 9 月 12 日受理)

\section{Cryogenic Structural Material and Design of Support Structures for the Large Helical Device}

\author{
Arata Nishimura, Shinsaku Imagawa and Hitoshi Tamura \\ National Institute for Fusion Science, 322-6 Oroshi, Toki 509-52
}

(Received September 12, 1997)

\begin{abstract}
Synopsis:
This paper describes a short history of material selection for the cryogenic support structures for the Large Helical Device (LHD) which has superconducting coils. Since the support structures are cooled down to $4.4 \mathrm{~K}$ together with the coils, SUS 316 was chosen because of its stable austenitic phase, sufficient mechanical properties at cryogenic temperature and good weldability. Also, outlines of the design and fabrication processes of the support structures are summarized. On the design of the support structures, a deformation analysis was carried out to maintain the proper magnetic field during operation. Afterwards, a stress analysis was performed. During machining and assembling, tolerance was noticed to keep coil positions accurate. Special welding grooves and fabrication processes were considered and achieved successfully. Finally, a cryogenic supporting post which sustains the cryogenic structures and superconducting coils is presented. CFRP was used in this specially developed supporting post to reduce the heat conduction from ambient $300 \mathrm{~K}$ structures.
\end{abstract}

Keywords: cryogenic structural material, SUS 316 stainless steel, structural design and fabrication, LHD

\section{1.はじめに}

大型ヘリカル装置（LHD）はすべてのコイルを超 伝導化した世界で初めての大型プラズマ実験装置であ り, $1 \mathrm{~m}$ 当たりの電磁力が 1,000 トンを越える巨大な 電磁力が発生する。この電磁力を支えながら, 精度良 い磁気面を確保するためには，正確に設計・製作され た電磁力支持構造物が必要となる。すべてのコイルが 超伝導化されているため, 支持構造物自体も $4.4 \mathrm{~K} に$ 冷却される。すなわちこの電磁力支持構造物は, 単体 に扔いてさえも約 400 トンに及ぶ巨大な極低温構造物 である。本稿では, これらの極低温構造物の材料選 択, 構造設計思想, 実際に行った製作について, それ

\section{らの概要を述べる。}

\section{2. 極低温構造材料の材料選択と機械的特性}

支持構造材料は極低温下で十分な強度, 靱性を有す るとともに，誤差磁場を低減するために非磁性でなけ ればならない。また, 機械加工性, 溶接性に優れてい る必要がある。このような要求を満たす材料として, 極低温機器での実績があり, また, 研究が進められて いたオーステナイト系ステンレス鋼 SUS 316 が採用 された。オーステナイト系ステンレス鋼は, Fig. 11 に示すように, 鋼中の炭素および窒素の含有量によっ て降伏強さが変化する。炭素を增加させると熱間加工 時に炭化クロムが粒界に析出し勒性が低下する。ま 




Fig. 1 Effect of $(\mathrm{C}+\mathrm{N})$ on tensile yield strength.

た，窒素を増加させると溶接時に欠陥が発生しやすく なる。後述する電子ビーム溶接性から図中に示す領域 を目標として設定した。

コイルの電流中心位置を精度良く確保するために は，溶接変形を極力小さくする必要がある。そのため にはエネルギー密度の高い電子ビーム溶接（EBW） が適している。健全な $\mathrm{EBW}$ 継手が得られる窒素濃度 と板厚の関係を Fig. 2 に示す。この結果より, LHD 用支持構造部材の最大板厚は $100 \mathrm{~mm}$ とし, 鋼中の窒 素濃度は $0.055 \sim 0.08$ mass\%とすることにした。ま た，炭素量は $0.04 \sim 0.05$ mass\%とし， $(\mathrm{C}+\mathrm{N})$ 量を $0.1 \sim 0.13$ mass\%とした。

大型ヘリカル装置では，下向きから上向きまですべ ての溶接姿勢が必要である。全姿勢での溶接に対して 高温割れを防止するため， $3 \%$ 程度の $\delta$ フェライを 有する共金溶接金属が得られる溶接ワイヤを開発し た。TIG ならびに MAG 溶接用ワイヤの化学組成の



械的性質を Table 2 に示す。 4 Kにおいても十分な延 性を示しており，溶接部の透磁率は 1.03 程度を示し た。

溶接入熱を低減し，溶着金属量を減らすことによっ て溶接変形を押さえることができる。そのため，支持 構造物の設計では部分溶け込み溶接を大幅に採用する こととした。この溶接法では溶接ルート部に溶け込み 不足等の溶接欠陥が生じることが危惧される。そこで Fig. 3 に示すような試験片を作製し，溶接ルート部 での破壊勒性，疲労き裂伝播速度を検討した。Fig. 4 は液体へリウム中での破壊勒性と降伏強度の関係を示 したもので2,3), $25 \mathrm{~mm}$ 厚さ以下の CT 試験片での結 果は従来の結果と良く一致しているが, 板厚 87.5



Fig. 2 Sound weld region of EBW in nitrogen content-plate thickness diagram.

Table 1 Chemical compositions of SUS316 and welding wires (mass\%).

\begin{tabular}{lccccccccc}
\hline \multicolumn{1}{c}{ Material } & $\mathrm{C}$ & $\mathrm{Si}$ & $\mathrm{Mn}$ & $\mathrm{P}$ & $\mathrm{S}$ & $\mathrm{Ni}$ & $\mathrm{Cr}$ & $\mathrm{Mo}$ & $\mathrm{N}$ \\
\hline SUS 316 & 0.04 & 0.63 & 0.76 & 0.023 & 0.000 & 10.90 & 17.29 & 2.27 & 0.062 \\
TIG 316CS & 0.06 & 0.33 & 6.47 & 0.003 & 0.002 & 16.58 & 17.51 & 2.33 & 0.032 \\
FCW316CS-H & 0.03 & 0.44 & 1.17 & 0.011 & 0.006 & 20.15 & 15.03 & 2.49 & 0.035 \\
\hline
\end{tabular}

Table 2 Tensile properties of SUS316 and weld joints at $4 \mathrm{~K}$

\begin{tabular}{lccccc}
\hline \multicolumn{1}{c}{ Material } & $\mathrm{E}(\mathrm{GPa})$ & $\mathrm{YS}(\mathrm{MPa})$ & $\mathrm{UTS}(\mathrm{MPa})$ & $\mathrm{EL}(\%)$ & $\mathrm{RA}(\%)$ \\
\hline Base Metal & 202 & 631 & 1,642 & 46.5 & 41.0 \\
TIG Joint & 199 & 800 & 1,368 & 30.4 & 36.5 \\
EBW Joint & 195 & 671 & 1,626 & 40.3 & 47.6 \\
\hline
\end{tabular}


$\mathrm{mm}$ の大型 3 点曲げ試験片での結果は約 1.5 倍程度高 い破壊靱性を示し，曲げに対して特に高い破壊抵抗を 示すことがわかる。ヘリカルコイル容器はその表面で 約 9 Tの磁場を経験するものと想定され，破壊勒性に 及ぼす磁場の影響を検討した4)。その結果を Fig. 5 に 示す。LHDで用いた SUS 316 母材およびTIG 溶接 金属は，強磁場中で勒性低下を生じないことが明らか になった。極低温下での疲労き裂伝播試験結果を Fig. 6 に示す5)。母材の結果は従来の結果とほぼ同じ 特性を示し，溶接ルート部から伝播したき裂は母材の それに比べ約 $1 / 5$ 低い伝播速度を示している。これ はルート部近傍に存在する溶接残留応力によるためで ある。

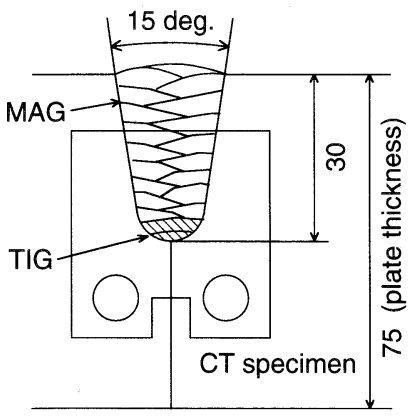

Fig. 3 Location of compact tension specimen in weld joint.

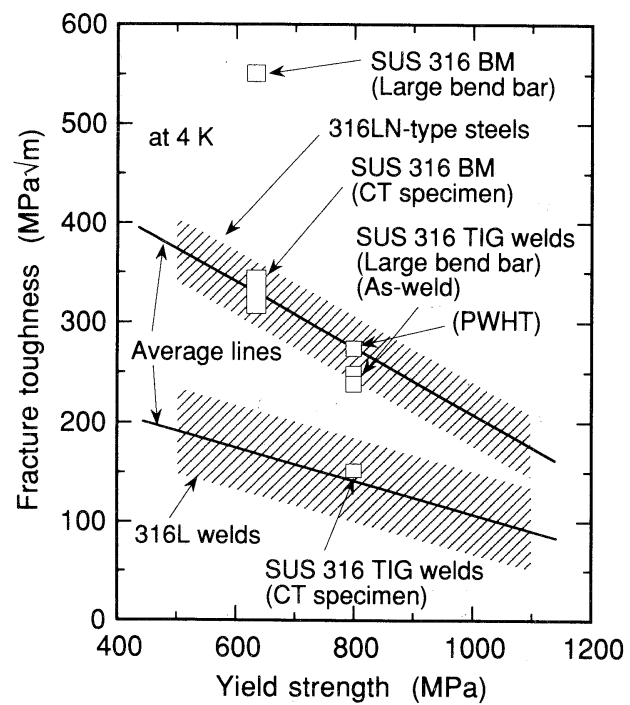

Fig. 4 Relation between fracture toughness and yield strength at $4 \mathrm{~K}$. PWHT: Post Weld Heat Treatment.

\section{3. 電磁力支持構造物の構造設計}

\section{1 設計指針と設計条件}

プラズマ閉じ込め性能に悪影響を及ぼす不整磁場を 抑制するため，ヘリカルコイルには高い製作精度と機 械剛性が要求される。大型へリカル装置の場合には, コイルの製作精度として $2 \mathrm{~mm}$ ，コイルの電磁力によ る変形については $3 \mathrm{~T}$ 通電時に $1.9 \mathrm{~mm}$ 以下，すな

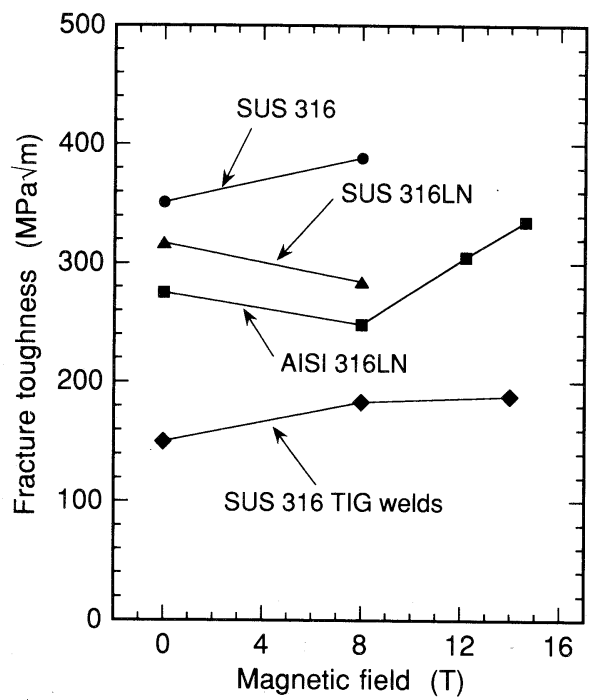

Fig. 5 Effect of magnetic field on fracture toughness at $4 \mathrm{~K}$.

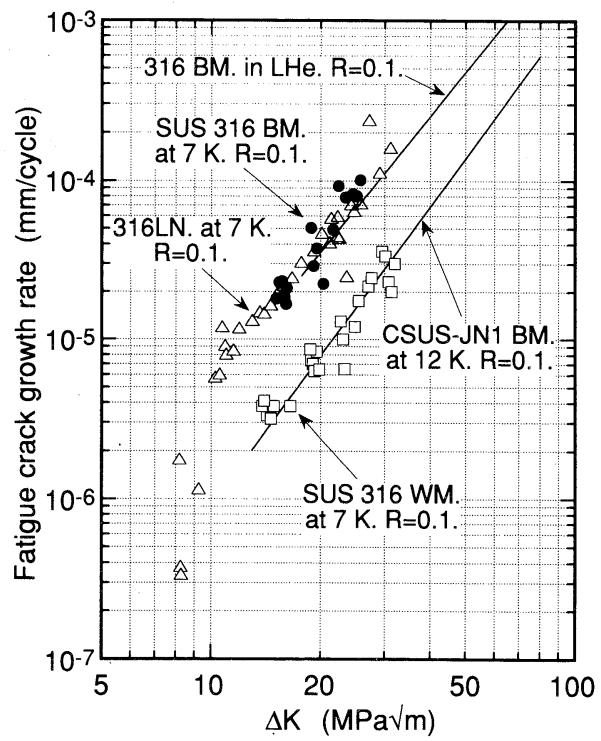

Fig. 6 Fatigue crack growth rates of stainless steels at cryogenic temperature.

低温工学 
わち $4 \mathrm{~T}$ 通電時に $3.4 \mathrm{~mm}$ 以下に収めることが指標 とされている。構造材料の許容応力に関しては ASME sec. III に準拠したが，オーステナイト系ステ ンレス鋼の極低温での材料強度は常温よりも 2 倍以上 になるので，合理的な設計を可能とするために使用温 度での材料強度から基準応力強さ $S_{\mathrm{m}}$ を求めることと した。電磁力支持構造物の設計フローを Fig. 7 に示 す。まず，電磁力による変形を評価して必要板厚を算 定し，応力が許容值を上回る場合には板厚あるいは形 状の変更を行った。溶接変形を抑制するために主に部 分溶接を採用したので，この部分に関しては応力拡大 係数を求めて破壊勒性值およびき裂進展を評価した。

大型ヘリカル装置の代表的な設計荷重条件を Table 3 に示す。使用年数としては 10 年を想定し, 最初の 3 年間はプラズマ中心磁場が $3 \mathrm{~T}$ の実験を行い, そ の後， $4 \mathrm{~T}$ に増強して 7 年間の実験を行う計画であ

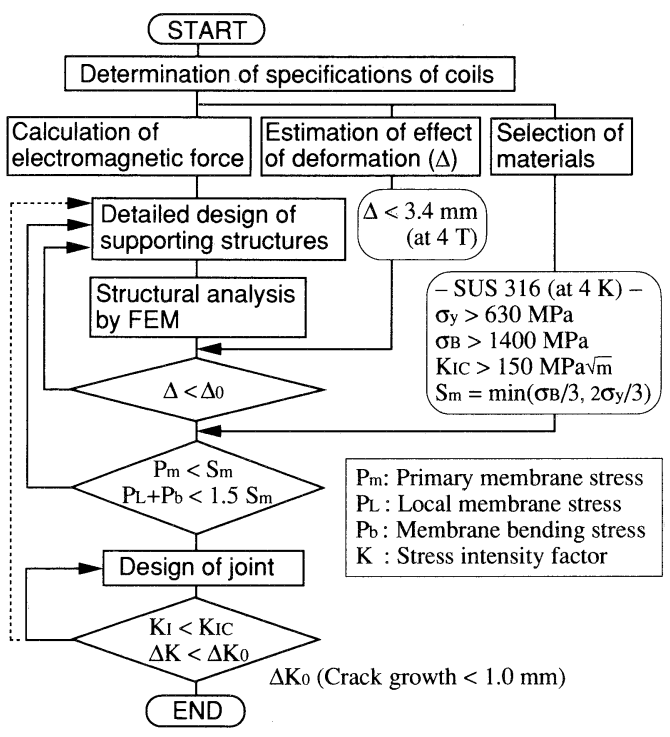

Fig. 7 Flowchart of the mechanical design of LHD.

Table 3 Representative design conditions of LHD.

\begin{tabular}{lr}
\hline Cooling down & 32 cycles \\
Coil excitation & 2,100 cycles \\
Operation mode transition & 310,000 cycles \\
Coil excitation time & $24,000 \mathrm{~h}$ \\
Plasma disruption $(150 \mathrm{kA}, 1 \mathrm{~ms})$ & 1,000 times \\
Current shut-off & 100 times \\
Earthquake $(0.3 \mathrm{G})$ & 10 times \\
\hline
\end{tabular}

Vol. 32 No. 11 (1997)
る。実験機器の取付と点検のための昇温・大気開放は 年 2 回を計画しており，他の期間は連続的に低温を維 持することになる。コイル励磁・消磁には各々 30 分 を必要をするので，プラズマ実験中は定格電流を維持 することを計画しており，励磁・消磁回数は毎日 1 回 ずつとなる。他に，プラズマディスラプション，コイ ル遮断，地震等の設計条件と回数が設定されている。

\section{2 コイルに働く電磁力}

機械的には第II期（4 T 通電）に耐え得る設計とす る必要がある。へリカルコイルに働く電磁力は小半径 方向のフープ力と転倒力に分解される。代表的な通電 モードに抢ける計算值を Fig. 8 に示すが， $10 \mathrm{MN} / \mathrm{m}$ を超える力が働くことが分かる6)。ポロイダルコイル に働く電磁力は大半径フープ力と軸方向への並進力 （上下力）に分解され，最大では $12 \mathrm{MN} / \mathrm{m}$ にも到達 する。ヘリカルコイルだけに通電する試験モードで は，ヘリカルコイル自身が作り出す垂直磁場によっ て, 小半径方向のフープ力が外周側で大きく内周側で 小さくなって，トーラス全体では外周側に拡がる力と なる。一方，実駼通電モードでは，この垂直磁場をポ ロイダルコイルが打ち消すので，ヘリカルコイルは， むしろ，トーラス内側に引き寄せられるょうになり，

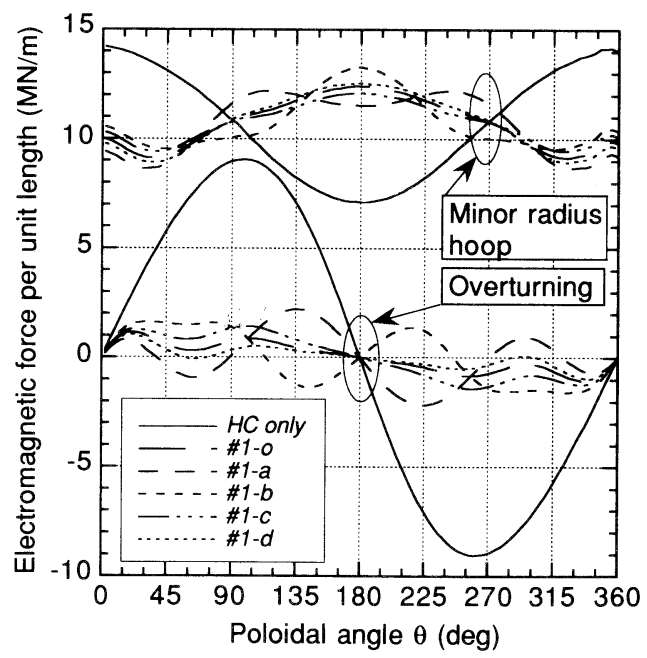

Fig. 8 Electromagnetic force on the helical coil of LHD. \#1-o, a, b, c and d are representative operating modes which mean standard, vertical elongation, horizontal elongation, outward shift and inward shift of plasma, respectively. When the poloidal angle $\theta$ is $0 \mathrm{deg}$, the helical coil locates in the outer mid-plane. 


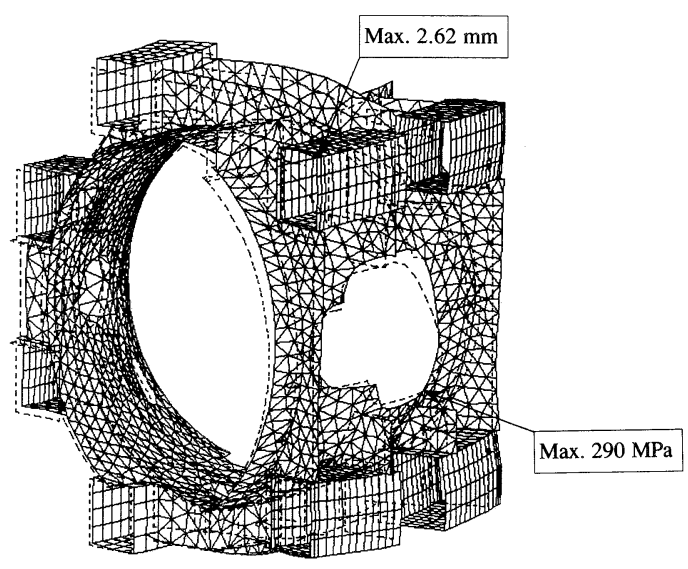

Fig. 9 One result of structural analyses of the supporting structure. Solid lines show the deformed shape at \#1-d mode, dashed lines show the original shape.

転倒力は $2.5 \mathrm{MN} / \mathrm{m}$ 以下に軽減される。ヘリカルコ イル単独通電の場合には $9 \mathrm{MN} / \mathrm{m}$ を超える転倒力が 働き，コイルの内部応力や支持構造物の応力分布が大 きく異なるので，合理的な設計を進めるために「通常 状態」から除外して構造最適化の際には対象外とする ことに決定した。

\section{3 構造物全体の構造解析}

ヘリカルコイルは導体自体では電磁力に対する強度 が不足するので, 液体 He 容器を兼ねたへリカルコイ ル容器 (HC 容器) に導体を収納し, 最終的にトーラ ス状の厚板構造物（支持シェル）によって外から支持 する構造を選択した。ポロイダルコイルはケーブル・ イン・コンジット導体で構成され，フープ力に対して はコイル自体で耐える設計が可能であるため，大半径 方向にも支持シェルに固定するかスライドさせるかを
選択することができる。固定する場合には支持シェル に働く全フープ力が大きくなるが，実験通電モードに おける全コイルの電磁力の合計はへリカルコイル単 独通電時にへリカルコイルに働く力の $10 \sim 30 \%$ の増 加に収まることから, 構造物の重量低減のためには完 全拘束の方が有利である。そこで，完全拘束を主案と して有限要素法による構造解析を実施した7)。解析に は汎用プログラムANSYS Revision 4.4 を用いた。 ポロイダルコイルは 3 次元ソリッド要素, 支持構造物 類は 3 次元板シェル要素で $1 / 10$ セクター分をモデル 化した。計算モデルの節点数・要素数を節約するため に, ヘリカルコイルは容器上蓋のみの剛性を考慮し, 導体等の剛性は無視した。

代表的な通電モードに対して，4 T 通電時の電磁力 を用いた解析結果を Table 4 にまとめる。ポロイダ ルコイルの剛性を考慮することによって, HC 容器と ポロイダルコイル固定座の最大変位量は共に $2.6 \mathrm{~mm}$ という結果が得られ，コイル自体の変形を含めてもコ イルの電流重心の最大変位が $3.4 \mathrm{~mm}$ 以内に収まる見 通しが得られた。電磁力支持構造物に生じるトレスカ 応力は，ポロイダルコイルの剛性を考慮しない場合で も $400 \mathrm{MPa}$ 以下であり, SUS 316 の極低温での 0.2 \%耐力（>630 MPa）以下に収まる結果が得られた。 解析で得られた最大トレスカ応力は 2 次応力を含んだ 值であるので十分な安全率が確保されていることにな る。変形抑制のために厚板構造物を採用したことが幸 いして応力面での裕度が確保されたので，溶接部には 未溶着部を残して変形を抑制する工夫を施すことが可 能となった。溶接深さは, $0.5 \mathrm{~mm}$ の初期き裂を想定 した場合の応力拡大係数を評価して，設計繰り返し荷 重によるき裂の進展を $1 \mathrm{~mm}$ 以内に抑えるように決定 した。き裂進展に対して支配的な設計荷重は，「定格

Table 4 Maximum stress intensity and displacement of the supporting structure of LHD.

\begin{tabular}{llccc}
\hline \multirow{2}{*}{ Operating mode } & \multirow{2}{*}{$\begin{array}{c}\text { Stress }(\mathrm{MPa}) \\
\text { Total }\end{array}$} & \multicolumn{2}{c}{ Displacement $(\mathrm{mm})$} \\
\cline { 4 - 5 } with PCs & & HC cans & PC support \\
& \#1-o & 277 & 2.38 & 2.46 \\
& \#1-a & 280 & 2.41 & 2.50 \\
& \#1-b & 243 & 1.73 & 2.36 \\
& \#1-d & 290 & 2.61 & 2.62 \\
& HC only & 154 & 2.86 & 1.46 \\
\hline \multirow{2}{*}{ without PCs } & HC only & 192 & 2.98 & 1.61 \\
& \#1-d & 367 & 3.01 & 3.19 \\
\hline
\end{tabular}

${ }^{*}$ PC means a poloidal coil. 
值までの励磁と消磁回数：2,100回」である。溶接収 縮を抑制するために未溶着部を残す場合には，溶接裏 波の確保と応力拡大係数の軽減を目的に溶接部先端に 応力緩和溝を設けた。この溝の形状はピーク応力を評 価して最適化を行った。

\section{4. 極低温構造物の製作}

\section{1 組立手順}

電磁力支持構造物およびへリカルコイルの容器, 蓋，シェルアームは，いずれも高い製作精度を要求さ れた。理想的には最終的な形状で，NCマシン等で機 械加工を行えばよいが，これらの構造物は完成時の直 径が $11 \mathrm{~m}$ を越えるため, 製作メーカーの工場からの 輸送が不可能である。そのため, 電磁力支持構造物 は，上下 2 分割および周方向に 10 分割した形状， へ リカルコイル容器は 1 本のコイルの $1 / 2$ ピッチを基 本部品として現地に持ち込み（コイル 2 本で合計 20 個)，接続部を溶接にすることによって，最終形状に する方法で製作した ${ }^{8)}$ 。

Fig. 10 に電磁力支持構造物の組立フロー, Fig. 11 に現地に運び込んだ基本部品 1 つ分の詳細図および溶 接形状を示す。溶接量を減らすために, 全板厚に対し



Fig. 10 Flowchart for construction of the supporting structure.

て部分溶け込みを採用している。セク夕間溶接部の中 央部は面接触のみとし，両側から溶接する構造とし

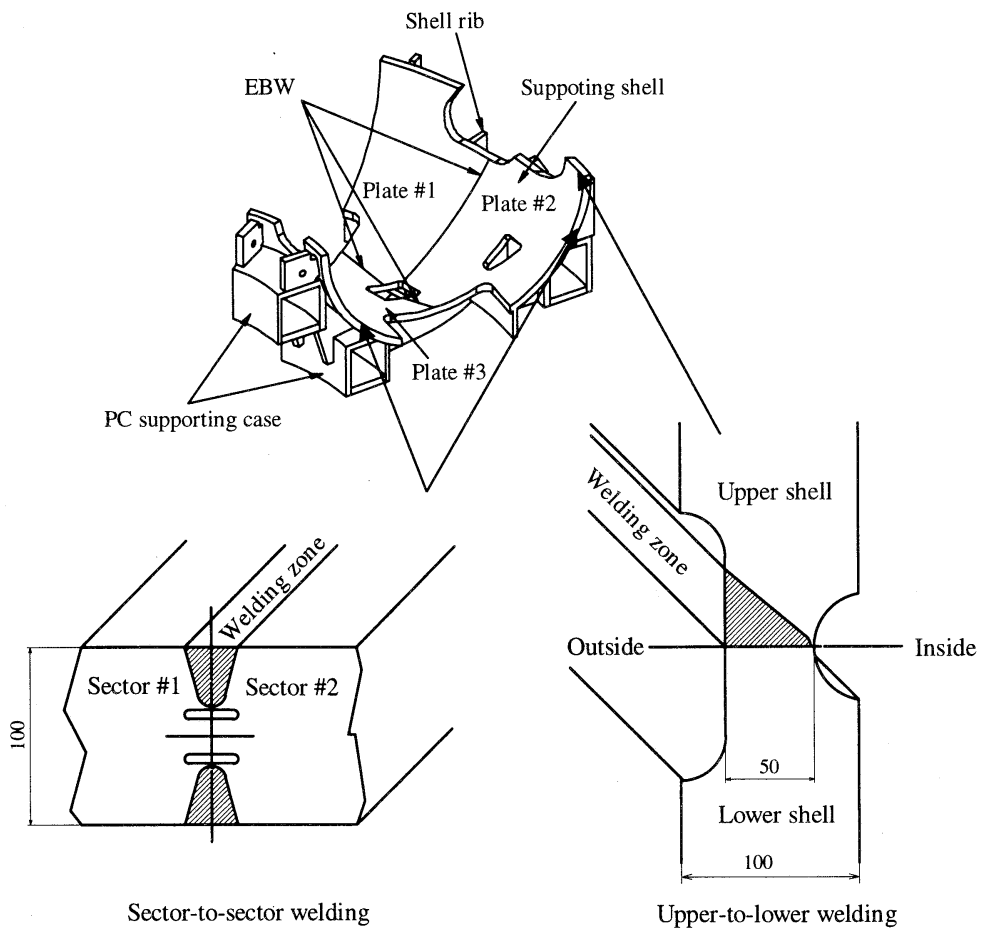

Fig. 11 Components in a sector of the supporting shell and design of weld joint. 
た。また，溶接開始部は応力集中の起こらない形状と している。上下間の溶接部では, 支持シェルの内面に ヘリカルコイルが設置された状態で溶接を行うため,

外側からのみの溶接とし，この部分の板厚を減肉する ことで溶接量を低減している。へリカルコイル容器は 工場内で $1 / 6 \sim 1 / 4$ ピッチの部品を加工し, EBW 溶 接によって $1 / 2$ ピッチの基本部品を製作し, 現地に

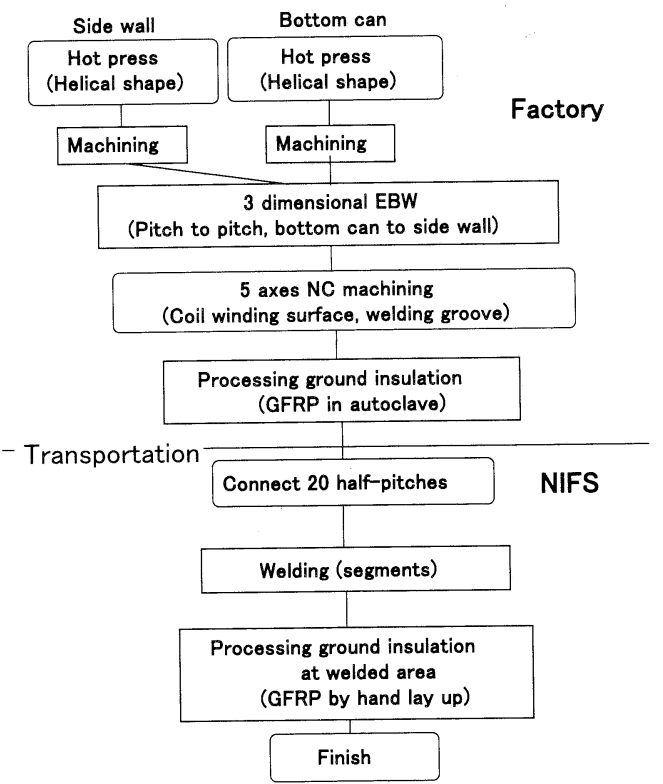

Fig. 12 Flowchart for construction of the helical coil can.



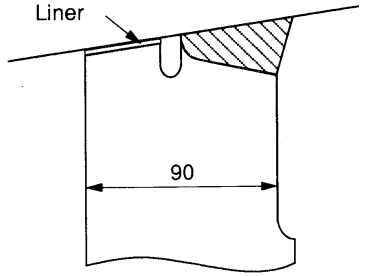

A (Shell arm and supporting shell)
持ち込んだ。Fig. 12, Fig. 13 にヘリカルコイル容器 の組立フローと溶接形状を示す。製作メーカの工場内 では，材料の板材のホットプレスによる基本形状への 加工，それらの電子ビーム溶接 $(\mathrm{EBW})$ および分割 された形状での NC マシンによる加工が行われたが, それぞれの構造物で特徵的な加工が行われている。電 磁力支持構造物の場合, 上半分と下半分それぞれが, セク夕間をボルト締結された状態で, 直径 $20 \mathrm{~m}$ の夕 ーニング加工機にかけられ，特に寸法精度が必要な支 持シェルの内面とポロイダルコイル固定座の内面およ び赤道面の溶接開先が加工された。その後再び分割さ れ, 現地へ輸送している。ヘリカルコイル容器の場合 は, 複雑な 3 次元形状であるため, 5 軸の $\mathrm{NC}$ マシ ンを使用し，精密に製作されている。

\section{2 現地組立}

現地組立では，溶接による入熱を押さえ，軸対称な 完成寸法にすることを目的に，溶接線を細かく分割し て実施された。電磁力支持構造物は，周方向に 10 分 割したセクタを単位として，1つのセクタは決まった 作業員が, 初層から終わりまで一貫して行い, セク夕 間の緊密な連携によって全体が均等に溶接されてい る。ヘリカルコイル容器は, 現地で 20 個の基本部品 を溶接した後, 超伝導導体の巻線が行われ, その後, 蓋が溶接されている。容器と蓋間の接続を一例にとる と, Fig. 14 に示すような手順で行われた。1つのセ グメントは内側と外側の溶接線がそれぞれ 6 つのブロ ックに分割され，さらにその 1 つのブロックは 7 つの

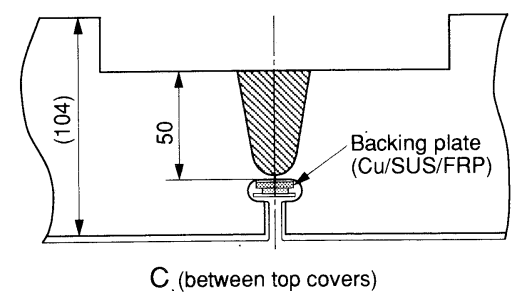

Fig. 13 Cross-sectional view of the helical coils and design of weld joint. 




Fig. 14 Welding process of the helical coil cover.

溶接作業単位に分けられている。1-(1)，1'-(1)，(2)(1)，2'-1)の順に溶接し，溶接変形をできるかぎり低 減させた。電磁力支持構造物の上下間およびへリカル コイルシェルアームとの接続も同様にして慎重に溶接 され，最終的にへリカルコイルと電磁力支持構造物を 接合した状態での組立精度は土 $2 \mathrm{~mm}$ を達成した。

\section{5. 断熱支持脚}

\section{1 構 造}

LHD の極低温構造物の総重量は，断熱支持脚によ って支持される。この断熱支持脚の役割として，(1) 構造物の重量を支え, 超伝導コイルの位置精度 $( \pm 2$ $\mathrm{mm}$ ) を確保すること，(2) 構造物の冷却，昇温による 熱変位 $(13 \mathrm{~mm})$ を吸収すること，(3) 極低温構造物 に対する常温からの伝導による熱侵入を極力低減する こと $(80 \mathrm{~K}$ に対し $600 \mathrm{~W}$ 以下， $4 \mathrm{~K}$ に対し $30 \mathrm{~W}$ 以

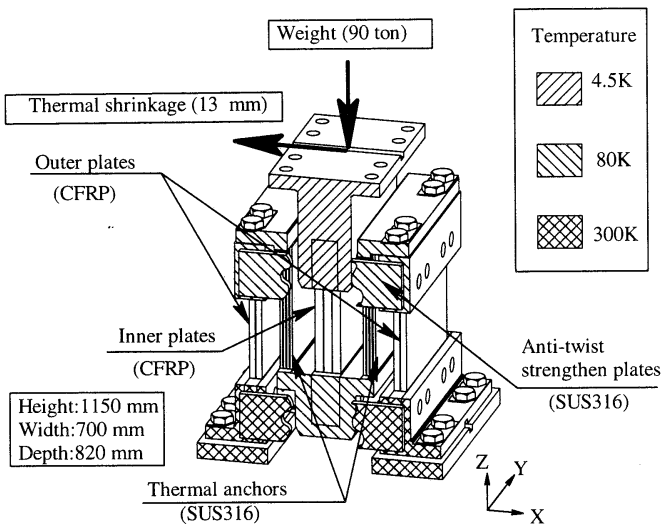

Fig. 15 Schematic of the cryogenic supporting post and its temperature level.
下), (4) 地震等の異常時（0.3 Gの横荷重）に対して 構造物の健全性を保つこと，が挙げられる。

LHD は構造上トロイダル角 $36^{\circ}$ の周期対称性があ るため，断熱支持脚は断熱真空容器の底板上の同心円

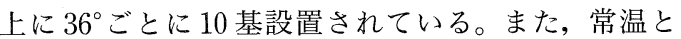
液体へリウム温度の断熱距離を大きくとり，しかも全 体の高さを低く押さえるために，折り曲げ構造を採用 している。Fig. 15 に断熱支持脚 1 基の概略と各部材 の温度分布を示す。図中でinner plates（内柱）と outer plates (外柱) はカーボン繊維強化複合材

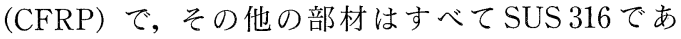
る。また， $X, Y, Z$ 方向はそれぞれ装置の主半径 方向，周方向，高さ方向を示している。断熱材として CFRP を採用したのは，50 K 以下での熱伝導率が通 常のガラス繊維強化材よりも小さく, 弾性率と圧縮強 度が高いためである。Table 5 に使用したCFRP 単 体の物性值を示す。表中の值は実機形状を模擬した

Table 5 Specifications of CFRP plate in the cryogenic supporting post.

\begin{tabular}{lll}
\hline \multicolumn{1}{c}{ Item } & & Unit \\
\hline Elastic modulus & & \\
$\quad$ Tensile & 61.8 & $\mathrm{GPa}$ \\
Bend & 60.8 & $\mathrm{GPa}$ \\
Strength (300 K/77 K) & & \\
Tensile & $607 / 589$ & $\mathrm{MPa}$ \\
Compressive & $614 / 781$ & $\mathrm{MPa}$ \\
Bend & $874 /-$ & $\mathrm{MPa}$ \\
Inter laminar shear & $65 /-$ & $\mathrm{MPa}$ \\
Thermal conductivity & $2.17 / 0.25 / 0.03$ & $\mathrm{~W} / \mathrm{mK}$
\end{tabular}


$120 \mathrm{~mm} \times 750 \mathrm{~mm}$ ，厚さ $22 \mathrm{~mm}$ のホットプレス製法 のCFRP を用いた実測值である。断熱の観点からは, CFRP の断面積を大きくし，長さを十分にとること が望ましいが，CFRP の座屈を避けるために，内柱 と外柱に分け，間にSUS 316 の $80 \mathrm{~K}$ レベルのサーマ ルアンカーを設けている。また，構造物の熱変位吸収 のためには柔軟な構造としたいため，サーマルアンカ 一部は板厚を薄くして，この部分の変形によって変位 を吸収する機構となっている。被冷却物の熱変位は, 設置時に断熱支持脚の常温側固定部を $6 \mathrm{~mm}$ だけ装置 中心側へオフセットしておくことによって，実際の冷 却時に断熱支持脚が受ける最大変位は $7 \mathrm{~mm}$ となるよ うに設置された。Table 6 に次節で述べる FEM 解 析9,10)によって求めた断熱支持脚の機械的な基本仕様 を示す。横荷重（ $Y$ 方向）と重量（ $Z$ 方向）に対し ては，支持脚の周方向の剛性によって十分強固な設計 となっている。

\section{2 耐震 解析}

LHD は設計条件として， $0.3 \mathrm{G}$ の横荷重に耐えら れることを仕様としている。設計した支持脚の構造 は，この仕様に対して十分な強度を有するようになっ ている。しかしながら，断熱支持脚単体での固有振動 数が地震などの振動数に近い場合は，極低温構造物を 含めたモード解析および模擬地震波に対する動解析が 必要となる。実際に支持脚の固有振動数を FEM で解 析した結果, 1 次モードで $12.7 \mathrm{~Hz}$ となり, 健全性 を確認するために動解析を実施した。

解析では，もとの形状のもつ機械的性質が損われな いように，モデルを簡略化する方法で計算を行った。 解析の手順は, 以下のとおりである。(1)詳細なモデ

Table 6 Equivalent spring constants and natural frequencies of the models for the cryogenic supporting post.

\begin{tabular}{crrr}
\hline & Model 1 & Model 2 & Model 3 \\
\hline Spring constant $(\mathrm{kN} / \mathrm{mm})$ & & \\
$X$ direction & 6.2 & 5.5 & 5.5 \\
$Y$ direction & 665.4 & 665.4 & 665.4 \\
$Z$ direction & 1270.0 & 1234.7 & 1234.7 \\
Natural frequency $(\mathrm{Hz})$ & & \\
Mode 1 & 12.7 & 13.5 & 13.9 \\
Mode 2 & 43.5 & 44.6 & 78.4 \\
Mode 3 & 53.2 & 76.9 & 82.7 \\
Mode 4 & 62.2 & 99.7 & 134.6 \\
Mode 5 & 101.1 & 119.9 & 193.9 \\
\hline
\end{tabular}

ルを作成し, 各方向の等価バネ定数と固有振動数を算 出する (model 1)。(2)すべて 3 次元シェル要素でモ デル化する。内外柱，サーマルアンカーはそれぞれ， 曲げに対する断面 2 次モーメントがもとの複数枚の板 と等価となる 1 枚の板とした (model 2)。(3) 質量, 主半径, 小半径が実際極低温構造物と同じ寸法のモデ ルを作成し，(2)で作成した支持脚モデルに乗せ，全 体の固有振動数を解析する。(4) 支持脚をバネ定数が (1) と等しい 1 枚の板 (model 3) に置き換え, 固有 振動数解析を行い，3 次モード程度までの振動数が (3) と同じになることを確認する。(5) 地震波形が横方向 の加速度として作用した場合の時刻歷応答解析を行 う。結果から断熱支持脚の付け根部分の変位を(1)の 詳細モデルに強制変位として作用させ, 各部の応力状 態を評価する。動解析に用いた地震波は震度 5 程度で 耐震解析によく使用されているEL-CENTRO であ る。また，断熱支持脚および電磁力支持構造物の減衰 定数は，すべての締結部分は溶接構造であるものとし て，0.5\%を用いた。実機には，CFRP とSUS 316 部との接続にはめ込み構造があるため, 減衰はこの值 よりも大きく，安全側の設計と考えられる。

Fig. 16 に入力波形の加速度, 半径方向の準静的な 応答, 半径方向の応答変位を示す。結果は, 半径方向 応答の場合で，地震による加速度が準静的に作用した 場合の 3 倍程度の応答加速度となった。ここで得られ た断熱支持脚と電磁力支持構造物の接続部での最大変 位を断熱支持脚の詳細モデルに強制変位として入力し
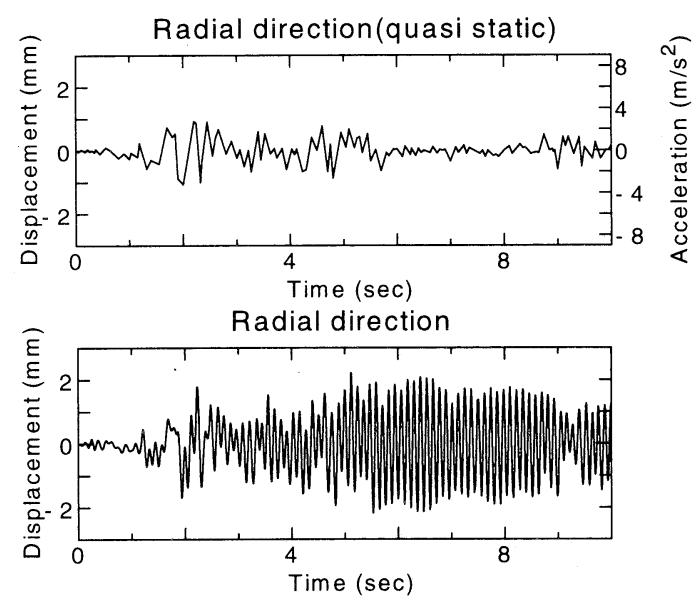

Fig. 16 Quasi static and dynamic response of the cryogenic supporting posts with the supporting structure and coils against EL-CENTRO earthquake. 
た結果，最大トレスカ応力は, $80 \mathrm{~K}$ 温度間を接続し ているSUS 316 の板部分で発生し，その值は 440 $\mathrm{MPa}$ となった。これは破壊に至る応力ではないが， 設計許容応力を越える結果となった。しかしながら， この部分は交換可能な部分であり, 減衰係数の裕度も 考慮すると，構造全体に影響を及ぼすには至らないと 予想される。結果として, 震度 5 程度の地震に対して 断熱支持脚は健全性を保つことが確認されている。

\section{6.おわりに}

大型ヘリカル装置の極低温構造物の材料選択，設計 指針，ならびに製作の概要を述べた。読者諸氏のご理 解の一助となれば幸いである。紙面の都合で説明が至 らない部分があろうかと危惧するが，参考文献を参照 して頂きたいと思う。

大型ヘリカル装置本体の設計・建設は，本島 修教 授，佐藤定男教授をはじめとする LHD 本体建設グル ープ，ならびに侏日立製作所関係各位の総力を結集し て遂行されている。これらの多くの方々に謝意を表す
るとともに，志半ばにして他界された山本純也先生の 献身的なご貢献に深く感謝致します。

\section{参 考 文 献}

1) N. J. Simon, et al.: Structural Materials for Superconducting Magnets, NBS (1985)

2) A. Nishimura, et al.: IEEE Trans. Magn. 32 (1996) 2941

3) A. Nishimura, et al.: Proc. of 16th ICEC/ICMC (1997) 1877

4) A. Nishimura, et al.: Adv. Cryog. Eng. 42 (1996) 315

5) A. Nishimura, et al.: ICMC, Portland (1997) GC 3

6) S. Imagawa, et al.: Fusion Eng. Design 20 (1993) 67

7) S. Imagawa, et al.: Adv. Cryog. Eng. 39 A (1994) 309

8) H. Tamura, et al.: CEC, Portland (1997) EE 1

9) H. Tamura, et al.: Fusion Technol. (1996) 1019

10) 田村 仁ら：平成 7 年度材料力学部門講演会講 演論文集（1996）209 